\title{
MRI-Based Angiogram
}

National Cancer Institute

\section{Source}

National Cancer Institute. MRI-Based Angiogram. NCI Thesaurus. Code C114867.

An image of blood vessels constructed using magnetic resonance imaging. 